DOI: $10.15193 /$ zntj/2020/122/325

\author{
LIDIA PIEKARSKA-RADZIK, ELŻBIETA KLEWICKA
}

\title{
WPLYW PREPARATU Z JAGÓD ACAI (EUTERPE OLERACEA) NA WLAŚCIWOŚCI POWIERZCHNIOWE, AUTOAGREGACJĘ I TWORZENIE BIOFILMU PRZEZ BAKTERIE Z RODZAJU LACTOBACILLUS
}

\begin{abstract}
Streszczenie
W ostatnich latach wzrosło zainteresowanie preparatami zawierającymi brazylijskie jagody acai (Euterpe oleracea). Ekstrakty z jagód acai charakteryzują się dużą zawartością związków organicznych, takich jak białka i lipidy. Uwagę zwraca się na prozdrowotne, a szczególnie przeciwutleniające właściwości tych owoców. Wysoki potencjał przeciwutleniający ekstraktów z jagód acai warunkowany jest dużą zawartością związków polifenolowych, jakie można izolować z ich miąższu. Związki polifenolowe obecne w ekstraktach roślinnych, spożywane przez ludzi i zwierzęta, w znacznym stopniu wpływają na modulację mikroflory jelitowej. W zależności od pochodzenia oraz zastosowanej dawki, mogą stawać się aktywatorami bądź inhibitorami wzrostu bakterii komensalnych. W niniejszej pracy poddano analizie wpływ preparatu z jagód acai na bakterie o potencjale probiotycznym z rodzaju Lactobacillus. Przeprowadzono analizę mającą na celu wyznaczenie współczynnika tworzenia biofilmu przez bakterie w zależności od obecności preparatu w podłożu hodowlanym. Sprawdzono, jak preparat z owoców acai wpływa na zdolność do autoagregacji i powinowactwo do rozpuszczalników organicznych. Przeprowadzone badania wykazały wpływ preparatu z jagód acai na zdolności autoagregacyjne bakterii Lactobacillus spp. (zmniejszenie autoagregacji szczepów Lactobacillus brevis i zwiększenie autoagregacji bakterii Lactobacillus casei). Wśród wszystkich badanych szczepów Lactobacillus spp. zauważono zmniejszenie zdolności tworzenia biofilmu w środowiskach z dodatkiem preparatu z jagód acai. Ponadto preparat z jagód acai wpłynął na właściwości typu donor/akceptor ścian komórkowych bakterii Lactobacillus spp.
\end{abstract}

Słowa kluczowe: Lactobacillus, jagody acai, autoagregacja, biofilm

\section{Wprowadzenie}

Drzewo palmowe - Euterpe oleracea jest jednym z 28 gatunków z rodzaju Euterpe występujących w dorzeczu Amazonki [3, 29]. W przemyśle spożywczym i farmaceutycznym zastosowanie znalazły jagody drzewa Euterpe oleracea zwane jagodami

Mgr inż. L. Piekarska-Radzik, prof. dr hab. inż. E. Klewicka, Instytut Technologii Fermentacji i Mikrobiologii, Wydz. Biotechnologii i Nauk o Żywności, Politechnika Łódzka, ul. Wólczańska 171/173, 90-924 Lódź. Kontakt: lidia.piekarska-radzik@dokt.p.lodz.pl 
acai. Centralną część każdego owocu stanowi duża (do $80 \%$ objętości) pestka. Zbiory jagód acai przypadają na cały rok kalendarzowy, jednak owoce zbierane między styczniem a lipcem cechują się mniejszą wartością odżywczą i niższą jakością sensoryczną. Miąższ jagód acai charakteryzuje się dużą zawartością związków fenolowych (w $100 \mathrm{~g}$ produktu znajduje się aż $328 \mathrm{mg}$ różnych związków bioaktywnych). W ekstrakcie z jagód acai całkowita zawartość związków o potencjale przeciwutleniającym jest 33-krotnie większa niż w ekstrakcie pochodzącym $\mathrm{z}$ winogron [2,3]. Polifenole jako przedstawiciele fitozwiązków (wtórnych metabolitów roślin), stanowią jedną z największych grup związków chemicznych o właściwościach przeciwutleniających [16, 18]. Liofilizat owocowy z jagód acai charakteryzuje się bardzo wysokim potencjałem przeciwutleniającym (1026 jednostek ORAC - ang. Oxygen Radical Absorbent Capacity) [3]. Jedną $\mathrm{z}$ dominujących grup związków polifenolowych izolowanych z owoców jagód acai stanowią antocyjany. Wśród wszystkich antocyjanów zawartych w pulpie z jagód acai, w największych ilościach występuje cyjanidyna i jej pochodne [10].

Duża zawartość tłuszczu sprawia, że jagody acai są niezwykle kaloryczne. Wartość energetyczna pulpy jagodowej wynosi blisko 534 kcal na $100 \mathrm{~g}$ suchej masy. Większość lipidów zawartych w jagodach acai to kwasy jednonienasycone (60\%), następnie kwasy nasycone (29\%) i lipidy wielonienasycone (11\%) [2]. Ponadto pulpa jagodowa Euterpe oleracea zawiera ponad $8 \mathrm{~g}$ białek i $44 \mathrm{~g}$ błonnika pokarmowego w 100 g suchej masy. Pod względem odżywczym białka występujące w miąższu owocowym należą do pełnowartościowych, a w ich budowie można wyodrębnić kompletne, zalecane porcje aminokwasów egzogennych. Jagody acai są również źródłem witaminy C, żelaza i wapnia [3].

W projektowaniu nowych produktów żywnościowych, atrakcyjnych dla konsumenta, stosuje się połączenie związków bioaktywnych i bakterii fermentacji mlekowej zaliczanych do składników żywności funkcjonalnej. Bakterie te stosowane są powszechnie w przetworach mlecznych, kiszonkach warzywnych i warzywnoowocowych, wędlinach fermentowanych czy kiszonej żywności orientalnej. W technologii żywności najchętniej wykorzystywane są bakterie z rodzaju Lactobacillus (LAB ang. lactic acid bacteria) [13, 27]. Bakterie te mają status GRAS (ang. Genareally Recognized as Safe), czyli są powszechnie uznawane za bezpieczne dla zdrowia człowieka. Na wzrost i rozwój bakterii Lactobacillus spp. ma wpływ wiele czynników, takich jak pH środowiska, temperatura otoczenia czy obecność związków bioaktywnych [27].

Związki pochodzenia roślinnego obecne w środowisku wzrostowym bakterii Lactobacillus spp. mogą ulegać przemianom metabolicznym, takim jak odszczepienie cząsteczki glukozy lub innego sacharydu, indukując tworzenie aglikonów [27]. Inną płaszczyzną oddziaływań polifenoli z mikroorganizmami są oddziaływania z ze- 
wnętrznymi strukturami bakterii, szczególnie białkami warstwy S. Białka powierzchniowe występujące $\mathrm{w}$ ścianach komórkowych bakterii mogą mieć różne struktury ( $\alpha$-helisy i $\beta$-harmonijki). Ich obecność w zależności od struktury jest aktywatorem bądź inhibitorem procesu autoagregacji i adhezji komórkowej (pierwszego etapu powstawania biofilmu) $[6,16,19]$. Oddziaływania polifenoli i białek warstwy $\mathrm{S}$ bakterii mogą być odpowiedzialne za zmiany właściwości powierzchni bakterii, takich jak: hydrofobowość, zdolność do akceptowania i oddawania elektronu czy autoagregacja [22].

Biofilm to rozbudowana struktura, która może zostać utworzona przez organizmy należące do tego samego lub różnych gatunków, stąd zdolność tworzenia biofilmów to nie tylko cecha bakterii, ale również pierwotniaków, grzybów oraz glonów $[4,5]$. Wielokomórkowe, przeważnie złożone struktury, zbudowane z dużej liczby mikroorganizmów otoczone są dodatkową warstwą śluzu [20]. Zewnątrzkomórkowe substancje polimerowe (EPS ang. - extracellular polymeric substance) stanowiące nawet do $50 \div$ 90 \% ogółu zawartości węgla w biofilmie, odpowiedzialne są za neutralizację lub przyłączanie innych substancji chemicznych. Jedną z podstawowych właściwości bakterii, która sprzyja tworzeniu struktur biofilmu jest ich zdolność do autoagregacji $[4,8]$.

Celem pracy było określenie wpływu preparatu z jagód acai na właściwości powierzchniowe, zdolność do autoagregacji i tworzenia biofilmu do powierzchni abiotycznych przez bakterie z rodzaju Lactobacillus.

\section{Material i metody badań}

Materiał biologiczny stanowiły 4 szczepy bakterii z rodzaju Lacobacillus: Lactobacillus brevis 0944, Lactobacillus brevis 0945, Lactobacillus brevis 0980 i Lactobacillus casei 0979 (przed reklasyfikacją opisywany jako Lactobacillus pentosus 0979). Wszystkie szczepy zostały zdeponowane w Kolekcji Czystych Kultur Przemysłowych ŁOCK 105 w Instytucie Technologii Fermentacji i Mikrobiologii Politechniki Łódzkiej.

W badaniach używano preparatu handlowego z jagód acai (A-Z Medica Sp. z o.o., Polska). Skład deklarowany przez producenta to standaryzowany sproszkowany ekstrakt z owoców acai (Euterpe oleracea) zamknięty w kapsułce (żelatyna, woda, barwniki: E171 - tlenek tytanu(IV), E172 - tlenki i wodorotlenki żelaza, substancja wypełniająca - maltodekstryna oraz substancja przeciwzbrylająca - stearynian magnezu). Jedna kapsułka zawierała $350 \mathrm{mg}$ masy nasypowej, w której udział polifenoli według deklaracji producenta (A-Z Medica Sp. z o.o, Polska) umieszczonej na opakowaniu produktu wynosił $10 \%(\mathrm{~m} / \mathrm{m})$. Autorzy dokonali analizy całkowitej zawartości związków polifenolowych w badanym ekstrakcie za pomocą metody Folina-Ciocalteu [11]. W badanym ekstrakcie oznaczono całkowitą sumę związków polifenolowych wynoszącą średnio $7,73 \%(\mathrm{~m} / \mathrm{m})$. Preparat A-Z Acai zbadano również pod względem 
zanieczyszczeń mikrobiologicznych zgodnie z Rozporządzeniem Komisji (WE) nr 2073/2005 z dnia 15 listopada 2005 roku w sprawie kryteriów mikrobiologicznych dotyczacych środków spożywczych [30]. W badanym ekstrakcie oznaczono ogólną liczbę bakterii na poziomie $10 \mathrm{jtk} / \mathrm{g}$ produktu, co nie dyskwalifikuje preparatu jako zdatnego do spożycia. Uzyskany w ten sposób wynik nie wpływa również znacząco na dalszą analizę preparatu. W preparacie nie stwierdzono obecności bakterii z rodzaju Lactobacillus.

\section{Powinowactwo do rozpuszczalników organicznych}

Test bakteryjnej adhezji do rozpuszczalników organicznych wykonywano metodą, którą opisali Ren i wsp. [25]. Hodowlę bakterii $(24 \mathrm{~h})$ odwirowywano (5 ml), a biomasę zawieszano w $5 \mathrm{ml}$ jałowego roztworu soli fizjologicznej. Zawiesinę komórek rozcieńczano dziesięciokrotnie. Następnie $3 \mathrm{ml}$ uzyskanej zawiesiny dodawano do $1 \mathrm{ml}$ rozpuszczalnika organicznego (w zależności od eksperymentu: ksylen - rozpuszczalnik niepolarny, charakteryzuje hydrofobowość ściany komórkowej bakterii; chloroform - rozpuszczalnik polarny, zmiana właściwości akceptorowych ściany komórkowej bakterii; octan etylu - rozpuszczalnik polarny, zmiana właściwości donorowych ściany komórkowej bakterii). Roztwór mieszano przez $1 \mathrm{~min}$, a następnie pozostawiano do rozdziału faz. W celu zmierzenia powinowactwa do rozpuszczalników pobierano $0,1 \mathrm{ml}$ frakcji wodnej i dodawano do 3,9 ml fizjologicznego roztworu soli o $\mathrm{pH}$ 7, następnie mieszano i mierzono absorbancję przy $\lambda=600 \mathrm{~nm}$ (Beckman DU-640, spektrofotometr UV-VIS, USA). Doświadczenie wykonywano analogicznie dla każdego szczepu hodowanego zarówno $\mathrm{z}$ dodatkiem preparatu z jagód acai, jak i bez niego. Jako próbę kontrolną przyjmowano absorbancję zawiesiny wyjściowej bez dodatku rozpuszczalnika. Wyniki pomiarów przedstawiano w postaci współczynnika powinowactwa do rozpuszczalnika (BATS - ang. bacterial adhesion to solvent), obliczonego $\mathrm{z}$ równania:

$$
\operatorname{BATS}[\%]=\left(1-\mathrm{A}_{5} / \mathrm{A}_{0}\right) \times 100
$$

gdzie: BATS - współczynnik powinowactwa do rozpuszczalnika, $\mathrm{A}_{0}$ - absorbancja zawiesiny wyjściowej, $\mathrm{A}_{5}$ - absorbancja fazy wodnej po 5 min.

\section{Zdolność autoagregacji}

Test autoagregacji bakterii z rodzaju Lactobacillus prowadzono metodą, którą opisali Ren i wsp. [25], po własnej modyfikacji. Zawiesinę bakterii przygotowywano analogicznie jak w przypadku eksperymentu powinowactwa do rozpuszczalników organicznych. Następnie $4 \mathrm{ml}$ zawiesiny przenoszono do nowej probówki i pozostawiano na $4 \mathrm{~h}$. W czasie $\mathrm{t}=0 \mathrm{~h}$ pobierano $0,1 \mathrm{ml}$ górnej fazy zawiesiny i dodawano do $3,9 \mathrm{ml}$ fizjologicznego roztworu soli o pH 7. Zawartość probówki mieszano i mierzono absor- 
bancję przy $\lambda=600 \mathrm{~nm}$ (Beckman DU-640, spektrofotometr UV-VIS, USA). Doświadczenie wykonywano analogicznie dla każdego szczepu hodowanego zarówno $\mathrm{z}$ dodatkiem preparatu $\mathrm{z}$ jagód acai, jak i bez niego, przy $\mathrm{t}=0 \mathrm{~h}$ oraz $\mathrm{t}_{\mathrm{n}}=4 \mathrm{~h}$. Wyniki pomiarów przedstawiano $\mathrm{w}$ postaci współczynnika zdolności do autoagregacji $\left(\mathrm{W}_{\mathrm{a}}\right)$ obliczonego według równania:

$$
\mathrm{W}_{\mathrm{a}}[\%]=\left(1-\mathrm{A}_{\mathrm{n}} / \mathrm{A}_{0}\right) \times 100
$$

gdzie: $\mathrm{W}_{\mathrm{a}}$ - współczynnik zdolności do autoagregacji, $\mathrm{A}_{0}-$ absorbancja próby w czasie $\mathrm{t}=0 \mathrm{~h}, \mathrm{~A}_{\mathrm{n}}-$ absorbancja próby w czasie $\mathrm{t}_{\mathrm{n}}$.

\section{Zdolność tworzenia biofilmu}

Zdolność do tworzenia biofilmu bakterii Lactobacillus spp. do powierzchni abiotycznych badano w polistyrenowych płytkach 6-dołkowych (Falcon), modyfikując metodę opisaną przez Stepanovica i wsp. [28]. Próbki bez dodatku preparatu z jagód acai stanowiły próbę kontrolną. W tym celu do każdej studzienki (komory) 6-dołkowej płytki wprowadzano podłoże MRS Broth (Merck, Polska) o objętości $3 \mathrm{ml}$ oraz $3 \mathrm{ml}$ podłoża z dodatkiem preparatu z jagód acai (mieszanina wyjściowa: $25 \mathrm{ml}$ MRS Broth + zawartość jednej kapsułki preparatu A-Z Acai). Następnie podłoże zaszczepiano 24-godzinną hodowlą badanego szczepu bakterii o objętości $1 \mathrm{ml}$ i poddawano 24-godzinnej inkubacji w temp. $30^{\circ} \mathrm{C}$. Po inkubacji podłoże usuwano, a każdą z komór przemywano 3-krotnie fizjologicznym roztworem soli. Próbki suszono i dodawano do każdej ze studzienek $2 \mathrm{ml}$ 0,05-procentowego roztworu fioletu krystalicznego. Płytki poddawano 45 -minutowej inkubacji na wytrząsarce $(90 \mathrm{rpm}) \mathrm{w}$ temp. $23 \pm 2{ }^{\circ} \mathrm{C}$, a następnie ponownie 3-krotnie przemywano komory fizjologicznym roztworem soli. Fiolet krystaliczny ekstrahowano 96-procentowym $(\mathrm{m} / \mathrm{m})$ etanolem i mierzono absorbancję przy długości fali $\lambda=490 \mathrm{~nm}$ (Beckman DU-640, spektrofotometr UV-VIS, USA). Wyniki przedstawiano w postaci współczynnika tworzenia biofilmu ( $\left.\mathrm{W}_{\mathrm{tb}}\right)$, obliczonego $\mathrm{z}$ równania:

$$
\mathrm{W}_{\mathrm{tb}}=\mathrm{A}_{\text {badane }} / \mathrm{A}_{\text {kontrolne }}
$$

gdzie: $\mathrm{W}_{\mathrm{tb}}-$ współczynnik tworzenia biofilmu, $\mathrm{A}_{\text {badane }}$ - absorbancja badanej próbki, A $_{\text {kontrolne }}$ - absorbancja samego podłoża.

Analiza statystyczna wyników

Uzyskane wyniki badań przedstawiono w postaci wartości średnich z co najmniej trzech niezależnie uzyskanych wyników. Obliczono także odchylenia standardowe. Do analizy statystycznej zastosowano test ANOVA Kruskala-Wallisa oraz test wielokrotnych porównań średnich rang przy $\mathrm{p}<0,05$. Obliczenia wykonano przy użyciu programu Statistica 12 (StatStoft). 


\section{Wyniki i dyskusja}

\section{Powinowactwo do rozpuszczalników organicznych}

Na podstawie wyników badań właściwości akceptorowych ściany komórkowej bakterii (rys. 1) można zauważyć, że szczepem, którego charakteryzowało największe powinowactwo do chloroformu był Lactobacillus brevis $0980\left(\mathrm{BATS}_{\mathrm{Ch}}=65,52 \%\right)$, natomiast szczepem, który wyróżniał się najmniejszym powinowactwem do tego rozpuszczalnika, był Lactobacillus brevis $0944\left(\mathrm{BATS}_{\mathrm{Ch}}=8,66 \%\right)$. Szczepy Lactobacillus brevis 0945 oraz Lactobacillus casei 0979 charakteryzowało podobne powinowactwo do chloroformu (w granicach $40 \div 45 \%$ ). Dodatek preparatu z jagód acai wpłynął na obniżenie powinowactwa do chloroformu w przypadku szczepu Lactobacillus brevis 0945 (o prawie $10 \%$ do wartości równej 31,06 \%) oraz szczepu Lactobacillus casei 0979 (o ok. $15 \%$ do wartości 28,76 \%). W przypadku szczepów: Lactobacillus brevis 0944 i Lactobacillus brevis 0980 dodatek preparatu z jagód acai wpłynął na wzrost powinowactwa do rozpuszczalnika o ponad $10 \%$. Wśród szczepów hodowanych z dodatkiem preparatu z jagód acai największe powinowactwo do chloroformu wykazał szczep Lactobacillus brevis $0980\left(\mathrm{BATS}_{\mathrm{Ch}}=77,74 \%\right)$, a najmniejsze - Lactobacillus brevis $0944\left(\mathrm{BATS}_{\mathrm{Ch}}=22,96 \%\right)$.

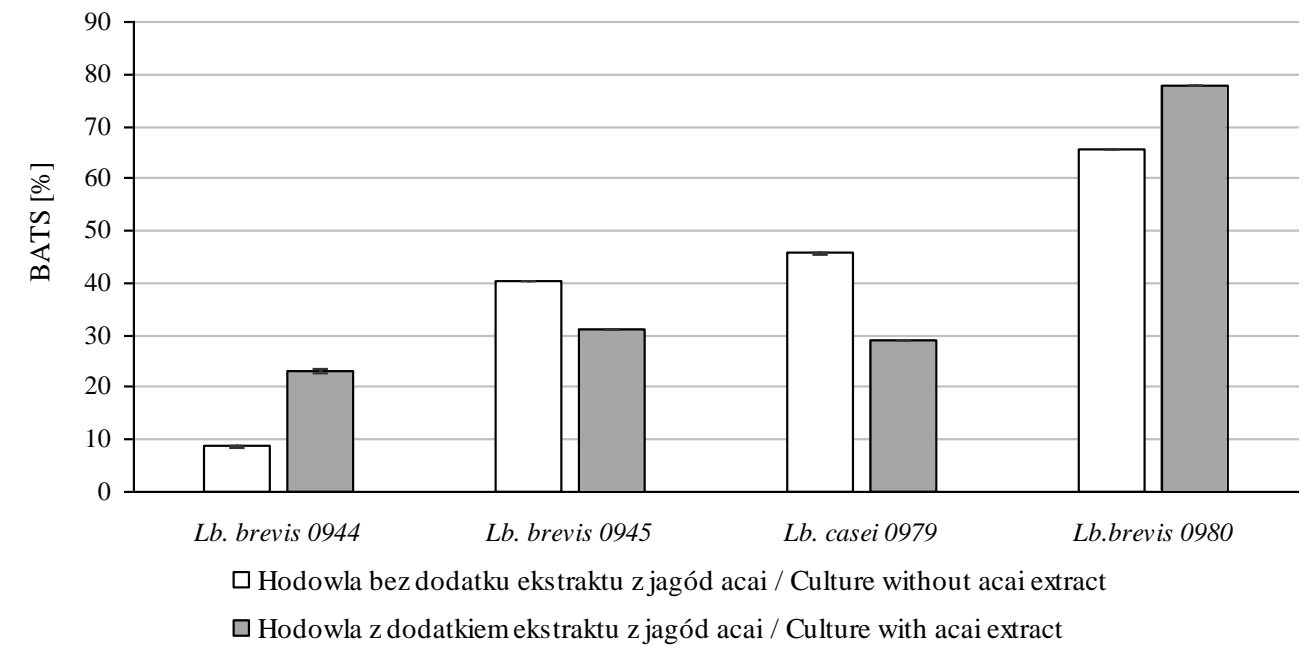

Objaśnienia / Explanatory notes:

$\mathrm{Na}$ rysunku przedstawiono wartości średnie (w postaci słupków) i odchylenia standardowe (w postaci odcinków) / Figure shows mean values (bars) and standard deviations (line segments)

Rys. 1. Zmienność wartości $\mathrm{BATS}_{\mathrm{Ch}} \mathrm{w}$ zależności od dodatku ekstraktu $\mathrm{z}$ jagód acai w stosunku do chloroformu

Fig. 1. Variability of BATS $\mathrm{Ch}_{\mathrm{Ch}}$ values depending on açai berry extract additive in relation to chloroform 


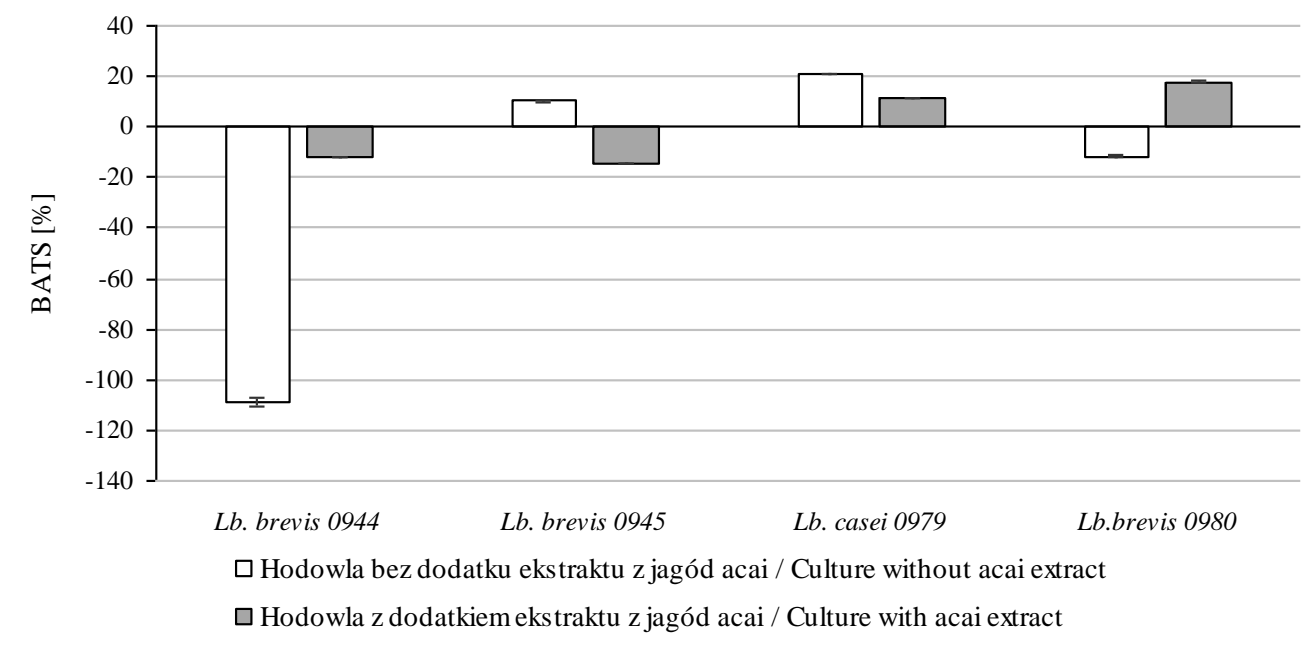

Objaśnienia jak pod rys. 1. / Explanatory notes as in Fig. 1.

Rys. 2. Zmienność wartości BATS $\mathrm{OE}_{\mathrm{E}} \mathrm{w}$ zależności od dodatku ekstraktu z jagód acai w stosunku do octanu etylu

Fig. 2. Variability of BATS $\mathrm{OE}_{\mathrm{E}}$ values depending on açai berry extract additive in relation to ethyl acetate

Na rys. 2. przedstawiono wyniki badań właściwości donorowych ścian komórkowych bakterii z rodzaju Lactobacillus. Szczepem, który charakteryzowało największe powinowactwo do octanu etylu był Lactobacillus casei $0979\left(\right.$ BATS $\left._{\mathrm{OE}}=20,93 \%\right)$, natomiast szczepem o najmniejszym powinowactwie do tego rozpuszczalnika był Lactobacillus brevis 0944 (BATS $\mathrm{OE}_{\mathrm{E}}=-108,92 \%$ ). Powinowactwo do octanu etylu szczepu Lactobacillus brevis 0945 oraz Lactobacillus brevis 0980 zawierało się w przedziale: $-12 \%<\mathrm{BATS}_{\mathrm{OE}}<11 \%$. Dodatek preparatu z jagód acai powodował zmniejszenie powinowactwa do octanu etylu $\mathrm{w}$ przypadku szczepu Lactobacillus brevis 0945 (o prawie $25 \%$ do wartości -14,53 \%) oraz szczepu Lactobacillus casei 0979 (o prawie $10 \%$ do wartości 11,52 \%). W przypadku szczepu Lactobacillus brevis 0944 stwierdzono znaczny wzrost powinowactwa do rozpuszczalnika (o ok. $90 \%$ ). Wzrost powinowactwa do octanu etylu zaobserwowano także w przypadku szczepu Lactobacillus brevis 0980 (o 29,25\%). Wśród szczepów hodowanych z dodatkiem preparatu z jagód acai największe powinowactwo do octanu etylu wykazał szczep Lactobacillus brevis $0980\left(\mathrm{BATS}_{\mathrm{OE}}=17,75 \%\right)$, a najmniejsze - Lactobacillus brevis $0945\left(\mathrm{BATS}_{\mathrm{OE}}=\right.$ $-14,53 \%)$.

Stwierdzono, że preparat z jagód acai ma właściwości osłabiające zdolność komórek bakterii Lactobacillus brevis 0945 oraz Lactobacillus casei 0979 do oddawania elektronów (bakterie stają się słabszymi donorami elektronów); podwyższa zaś tę zdolność w przypadku bakterii Lactobacillus brevis 0944 oraz Lactobacillus brevis 
0980. Wyniki przeprowadzonej analizy pozwalają również zauważyć zmiany powinowactwa komórek bakteryjnych do chloroformu, który miał na celu określenie zmian w akceptowaniu elektronów. Szczepy Lactobacillus brevis 0944 i Lactobacillus brevis 0980 stawały się silniejszymi akceptorami po dodaniu preparatu z jagód acai. W przypadku szczepu Lactobacillus brevis 0945 i Lactobacillus casei 0979 preparat z jagód acai wpływał na zmniejszenie właściwości akceptorowych ścian komórkowych tych bakterii.

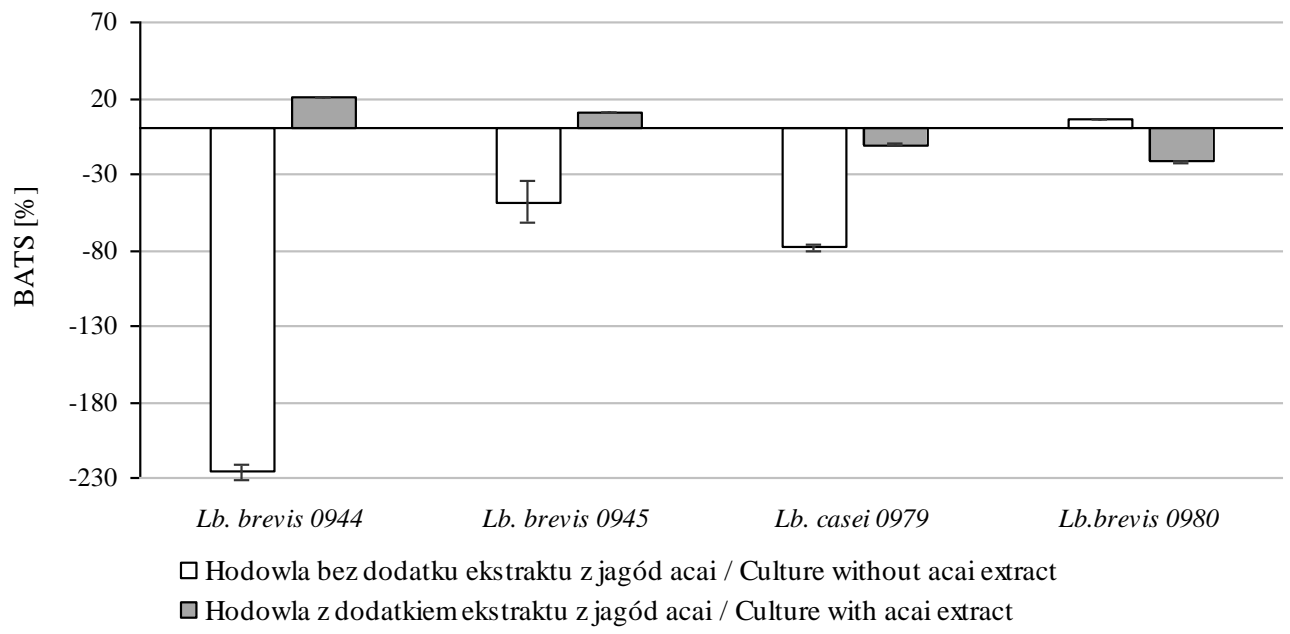

Objaśnienia jak pod rys. 1. / Explanatory notes as in Fig. 1.

Rys. 3. Zmienność wartości $\mathrm{BATS}_{\mathrm{K}} \mathrm{w}$ zależności od dodatku ekstraktu z jagód acai w stosunku do ksylenu

Fig. 3. Variability of $\mathrm{BATS}_{\mathrm{K}}$ values depending on açai berry extract additive in relation to xylene

Dowiedziono, że preparat z jagód acai umożliwił zmianę charakteru powierzchni ściany komórkowej bakterii, tj. zmianę typu donor/akceptor. $\mathrm{W}$ doświadczeniu potwierdzono opisaną wyżej zależność w przypadku trzech na cztery badane szczepy. Odmiennie zachowywały się bakterie szczepu Lactobacillus brevis 0944. Na podstawie wyników badania hydrofobowości ścian komórkowych bakterii (rys. 3) stwierdzono, że szczepem, który wykazywał największe powinowactwo do ksylenu był Lactobacillus brevis $0980\left(\mathrm{BATS}_{\mathrm{K}}=5,99 \%\right)$, natomiast szczepem, który charakteryzowało najmniejsze powinowactwo do tego rozpuszczalnika był Lactobacillus brevis 0944 $\left(\right.$ BATS $\left._{\mathrm{K}}=-226,29 \%\right)$. Dodatek preparatu z jagód acai wpływał na zmniejszenie powinowactwa do ksylenu w przypadku szczepu Lactobacillus brevis 0980 (o prawie $28 \%$ ), natomiast w przypadku szczepu Lactobacillus brevis 0944 stwierdzono znaczny wzrost powinowactwa do rozpuszczalnika (blisko o $247 \%$ ). Wzrost powinowactwa do ksylenu zaobserwowano również w przypadku szczepu Lactobacillus brevis 0945 
i Lactobacillus casei 0979 (o $60 \div 70$ \%). Wśród szczepów hodowanych z dodatkiem preparatu z jagód acai największe powinowactwo do ksylenu wykazał szczep Lactobacillus brevis 0944 BATS $_{\mathrm{K}}=20,50 \%$ ), a najmniejsze - Lactobacillus brevis 0980 $\left(\right.$ BATS $\left._{\mathrm{K}}=-21,95 \%\right)$.

Zdolność autoagregacji

Zmiany autoagregacji komórek bakterii z rodzaju Lactobacillus (po $4 \mathrm{~h}$ prowadzenia doświadczenia) w zależności od dodatku preparatu z jagód acai do podłoża hodowlanego przedstawiono na rys. 4. Szczep Lactobacillus brevis 0944 hodowany w podłożu bez dodatku preparatu z jagód acai charakteryzował się większą zdolnością do autoagregacji $\left(\mathrm{W}_{\mathrm{a}}=77,21 \%\right)$ niż $\mathrm{w}$ przypadku hodowli $\mathrm{z}$ dodatkiem preparatu $\mathrm{z}$ jagód acai $\left(\mathrm{W}_{\mathrm{a}}=35,23 \%\right)$. Szczep Lactobacillus brevis 0945 hodowany w podłożu niezawierającym dodatku preparatu z jagód acai cechował się również większą zdolnością do autoagregacji $\left(\mathrm{W}_{\mathrm{a}}=65,62 \%\right)$ niż hodowla $\mathrm{z}$ dodatkiem preparatu $\mathrm{z}$ jagód acai $\left(\mathrm{W}_{\mathrm{a}}=46,55 \%\right)$. Szczep Lactobacillus brevis 0980 hodowany w podłożu bez preparatu z jagód acai charakteryzował się zdolnością do autoagregacji na poziomie 47,22 \%, natomiast $\mathrm{w}$ przypadku hodowli $\mathrm{z}$ dodatkiem preparatu $\mathrm{z}$ jagód acai jego zdolność do autoagregacji zmniejszyła się do $18,11 \%$. Stwierdzono, że dodatek preparatu z jagód acai wpłynął na zmniejszenie zdolności autoagregacji szczepu Lactobacillus brevis 0944 o 49,98 \%, Lactobacillus brevis 0945 - o 19,07 \%, a Lactobacillus brevis 0980 -

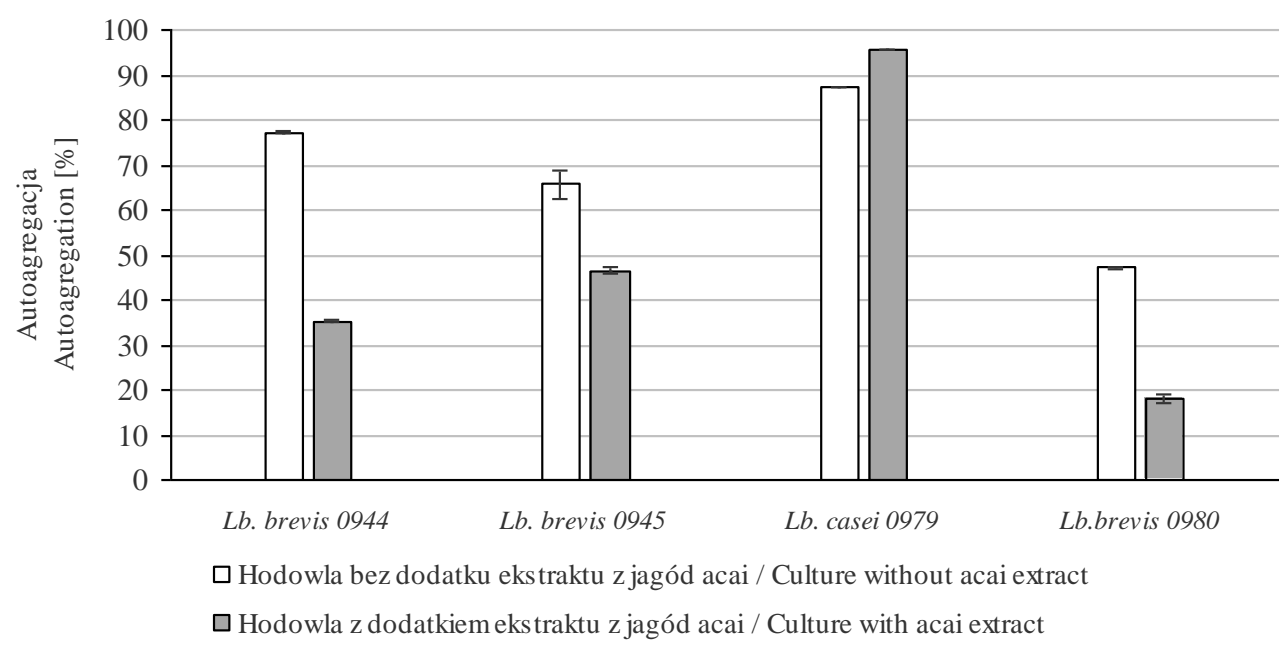

Objaśnienia jak pod rys. 1. / Explanatory notes as in Fig. 1.

Rys. 4. Zmiana zdolności autoagregacyjnych bakterii z rodzaju Lactobacillus w zależności od dodatku ekstraktu z jagód acai

Fig. 4. Change in autoagreggation abilities of Lactobacillus bacteria depending on açai extract additive 
o 29,11\%. Szczep Lactobacillus casei 0979 hodowany w podłożu zawierającym dodatek preparatu z jagód acai charakteryzował się większą zdolnością do autoagregacji $\left(\mathrm{W}_{\mathrm{a}}=95,55 \%\right)$ niż $\mathrm{w}$ przypadku hodowli bez dodatku preparatu $\mathrm{z}$ jagód acai $\left(\mathrm{W}_{\mathrm{a}}=\right.$ $87,35 \%$ ). Szczepem wykazującym największe zdolności autoagregacji wśród badanego materiału biologicznego był Lactobacillus casei 0979, zarówno w hodowli bez dodatku preparatu z jagód acai, jak również z jego udziałem.

Zdolność do autoagregacji i kolonizacji powierzchni biotycznych (takich jak błony śluzowe gospodarza) to jedna $\mathrm{z}$ najbardziej pożądanych cech probiotycznych szczepów bakterii z rodzaju Lactobacillus. Bakterie z rodzaju Lactobacillus wykazują również zdolność przylegania do powierzchni abiotycznych (np. szkła bądź polistyrenu). Ponadto pozakomórkowe substancje polimerowe wytwarzane $\mathrm{w}$ procesie przyrastania biofilmu przez wiele bakterii z rodzaju Lactobacillus sprawiają, że wielokomórkowa struktura często wykazuje właściwości antagonistyczne w stosunku do mikroflory patogennej [14]. Złożony proces adhezji komórkowej dotyczy kontaktu błony komórkowej i powierzchni. Badania hydrofobowości ścian komórkowych i ruchliwości elektrycznej stanowią podstawę oceny uzdolnień adhezyjnych bakterii. Są one bowiem związane ze składem chemicznym ścian komórkowych. Tym samym adhezja zależy nie tylko od oddziaływań van der Waalsa, ale również od sił elektrostatycznych, stąd szczepy dobrze przylegające do węglowodorów uważa się za hydrofobowe, natomiast szczepy pozbawione tej zdolności - za hydrofilowe [9].

\section{Zdolność tworzenia biofilmu}

Zmiany współczynnika tworzenia biofilmu $\left(\mathrm{W}_{\mathrm{tb}}\right)$ 24-godzinnych hodowli badanych szczepów bakterii $\mathrm{w}$ zależności od obecności preparatu $\mathrm{z}$ jagód acai przedstawiono na rys. 5. Stwierdzono, że dodatek preparatu z jagód acai wpłynął na zmniejszenie zdolności tworzenia biofilmu w przypadku wszystkich badanych szczepów bakterii z rodzaju Lactobacillus. Wśród badanych bakterii największą zdolność tworzenia biofilmu stwierdzono w przypadku szczepu Lactobacillus casei 0979, którego współczynnik tworzenia biofilmu wynosił $\mathrm{W}_{\mathrm{tb}}=55,45$. Najmniejszą zdolnością tworzenia biofilmu charakteryzował się szczep Lactobacillus brevis 0980, którego zdolność tworzenia biofilmu wynosiła $\mathrm{W}_{\mathrm{tb}}=6,26$. Szczepy Lactobacillus brevis $0944 \mathrm{i}$ Lactobacillus brevis 0945 miały podobną zdolność tworzenia biofilmu wyrażoną współczynnikiem tworzenia biofilmu w zakresie: $9<\mathrm{W}_{\mathrm{tb}}<10$. Największą zdolność do tworzenia biofilmu w obecności preparatu z jagód acai wykazywał szczep Lactobacillus brevis 0944 $\left(\mathrm{W}_{\mathrm{tb}}=4,05\right)$. Szczepy Lactobacillus brevis 0980 i Lactobacillus casei 0979 miały podobną zdolność tworzenia biofilmu na podłożu z dodatkiem preparatu z jagód acai, charakteryzowaną współczynnikiem tworzenia biofilmu w zakresie: $3<\mathrm{W}_{\mathrm{tb}}<3,5$. 


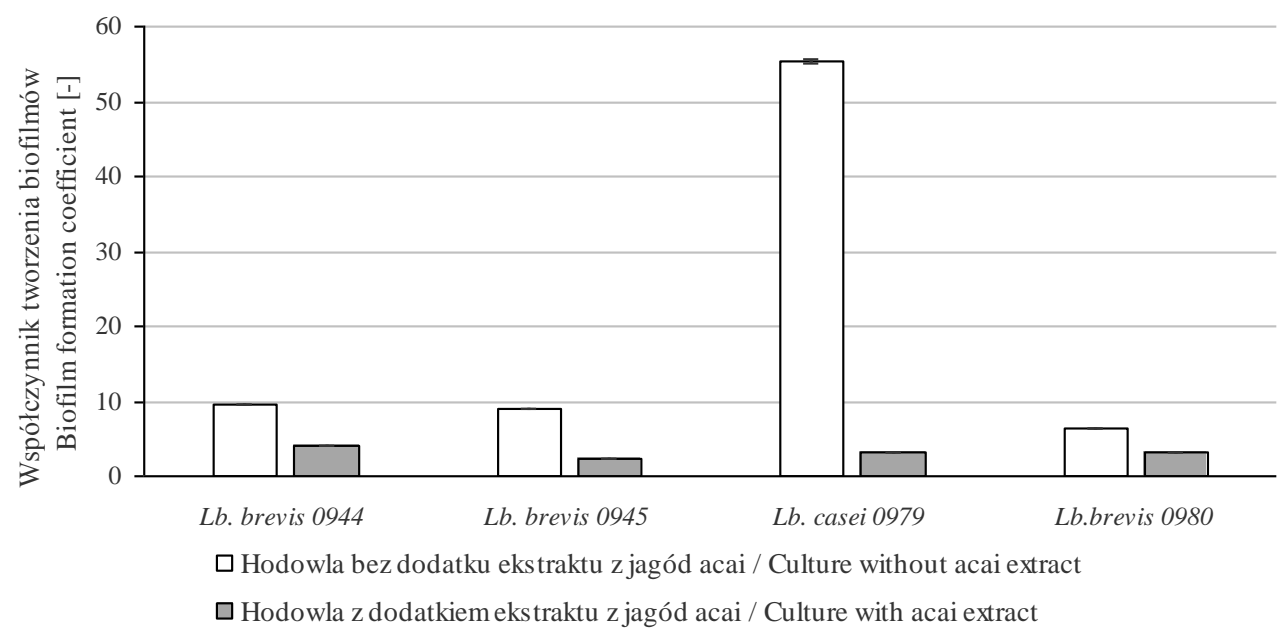

Objaśnienia jak pod rys. 1. / Explanatory notes as in Fig. 1.

Rys. 5. Zdolność do tworzenia biofilmu w zależności od dodatku ekstraktu z jagód acai

Fig. 5. Biofilm formation ability depending on açai extract additive

Zdolność tworzenia biofilmu przez bakterie fermentacji mlekowej związana jest przede wszystkim z ich właściwościami adhezyjnymi. Adhezja jako pierwszy etap powstawania biofilmu stanowi bowiem jeden z najważniejszych etapów przy formacji wielowarstwowej struktury. Według teorii DLVO oddziaływania między ścianą komórkową bakterii a powierzchnią, do której mają one przylegać, związane są z sumą oddziaływań siły van der Waalsa (działania przyciągające) i oddziaływaniami elektrostatycznymi (działania odpychające). Przed utworzeniem struktury biofilmu (kiedy komórki bakterii są oddalone od siebie) czynnikiem decydującym o inicjacji tworzenia wielokomórkowej struktury jest zazwyczaj siła oddziaływania grawitacji oraz stopień hydrofobowowści ścian komórkowych [7, 12]. Przyleganie bakterii do powierzchni biotycznych i abiotycznych związane jest ze zdolnością do tworzenia specyficznych i niespecyficznych wiązań. Charakterystyczną cechą wiązań niespecyficznych jest ich odwracalność. Są one związane z tworzeniem oddziaływań przestrzennych na drodze oddziaływań elektrostatycznych i hydrofobowych. Tym samym hydrofobowość powierzchni bakterii odgrywa kluczową rolę w kontakcie między bakterią a powierzchnią np. nabłonka [24].

Łatwiejsza i podwyższona adhezja komórek bakterii, dzięki której rodzaj Lactobacillus zdolny jest do kolonizacji organizmu gospodarza może wynikać z wysokiej hydrofobowości ścian komórkowych. Polak-Berecka i wsp. [24] nie zgadzają się z powyższą tezą. Ze środowiska izolowane są szczepy bakterii z rodzaju Lactobacillus, które mimo wysokiej hydrofobowości nie wykazują zdolności do adhezji. Jak podają 
Munoz-Provencio i wsp. [21], izoluje się również gatunki bakterii, które silnie adherują do komórek nabłonka nawet w sytuacji, kiedy cechuje je niska hydrofobowość. Zjawisko takie autorzy zaobserwowali w przypadku szczepów Lactobacillus brevis 0944, Lactobacillus brevis 0945 i Lactobacillus casei 0979. Adhezja komórek bakteryjnych wiąże się z dwoma zasadniczymi mechanizmami: wiązaniem specyficznym i niespecyficznym. Oddziaływania elektrostatyczne oraz hydrofobowe charakteryzuje niższe powinowactwo niż przy wiązaniach specyficznych [9]. Piette i Idziak [23] podają, że ładunek powierzchniowy ściany komórkowej w korelacji z hydrofobowością może znacznie wpływać na siłę adhezji. Z kolei Lim i Ahn [17] uważają, że silna hydrofobowość bakterii fermentacji mlekowej (zarówno w heksadekanie jak i w toluenie) może świadczyć o ewentualnym potencjale probiotycznym badanych szczepów. Ich zdaniem adhezja komórek bakterii probiotycznych może jednak zależeć również od czynników środowiskowych, wśród których wyróżnić należy skład medium, pH i temperaturę oraz obecność jonów $\mathrm{Ca}^{2+}$. Wpływ ekstraktu z jagód acai na mikroorganizmy (w tym bakterie z rodzaju Lactobacillus) nie jest dokładnie zbadany. Najlepiej poznanym aspektem ekstraktów z tych owoców jest bez wątpienia ich skład chemiczny. Związki bioaktywne zawarte w owocach acai mogą również wpływać na metabolizm oraz budowę komórki. Tym samym przeprowadzone badania potwierdzają specyfikę i zindywidualizowanie charakteru właściwości powierzchniowych ścian komórkowych bakterii z rodzaju Lactobacillus. Różnice te mają odzwierciedlenie w zjawiskach autoagregacji i formowaniu biofilmu w środowisku zawierającym ekstrakty roślinne. Niestety, mimo wysokiej hydrofobowości ścian komórkowych bakterie: Lactobacillus brevis 0944 oraz Lactobacillus brevis 0945 cechowały się mniejszą zdolnością do autoagregacji w środowisku z dodatkiem ekstraktu z jagód acai.

Warto podkreślić, że różnice $\mathrm{w}$ adhezji i agregacji komórek bakterii fermentacji mlekowej mogą wynikać $\mathrm{z}$ różnic $\mathrm{w}$ budowie chemicznej ścian komórkowych. Wzrost hydrofobowości ścian komórkowych często związany jest $\mathrm{z}$ obecnością białek występujących na ich powierzchni. Z kolei obecność polisacharydów w strukturach powłok komórkowych sprawia, że powierzchnia komórek bakteryjnych wykazuje właściwości hydrofilowe [1]. Ponadto poprzez tworzenie kompleksów z makro- i mikroelementami polifenole wpływają na ilość magazynowanych jonów we wnętrzach komórek lub zmieniają przyswajalność substancji odżywczych obecnych w podłożu hodowlanym [25]. W procesie agregacji komórek LAB biorą udział nie tylko białka i liporoteiny umiejscowione w błonach komórkowych. Znaczącą rolę odgrywają także białka, które wydzielane są do środowiska zewnętrznego [26]. Oprócz metabolitów komórek bakterii, w środowisku istnieją również mediatory biorące udział w procesie agregacji. Kos i wsp. [15] dowiedli, że komórki szczepu Lactobacillus acidophilus M92 po procesie trawienia proteolitycznego wykazywały niższą hydrofobowość, a tym samym zmniejszyły się ich zdolności agregacyjne. W badaniach własnych zaobserwowano również, 
że ekstrakt z jagód acai wpływał na właściwości typu donor/akceptor oraz hydrofobowość.

W przeprowadzonych badaniach wykazano, że obecność w środowisku ekstraktów roślinnych, w tym przypadku ekstraktu z jagód acai, może zmieniać właściwości powierzchniowe komórek bakterii z rodzaju Lactobacillus oraz związane z tymi właściwościami zjawiska autoagregacji i zdolności do tworzenia biofilmów. W przypadku bakterii Lactobacillus spp., które są bioaktywnym składnikiem żywności fermentowanej i funkcjonalnej, obniżenie ich potencjału do autoagregacji i tworzenia biofilmu w niszy ekologicznej, jaką jest przewód pokarmowy człowieka, będzie efektem niekorzystnym. Podczas projektowania żywności fermentowanej na bazie surowca roślinnego oraz z dodatkiem ekstraktów roślinnych należy zatem określić ewentualne pozytywne i negatywne oddziaływania pomiędzy składnikami bioaktywnymi surowca i bakteriami Lactobacillus spp.

\section{Wnioski}

1. Ekstrakt z jagód acai obniża zdolność do autoagregacji bakterii z gatunku Lactobacillus brevis.

2. Jagody acai powodują zmniejszenie zdolności tworzenia biofilmu przez badane bakterie o potencjale probiotycznym z rodzaju Lactobacilllus oraz zmieniają właściwości typu donor/akceptor ścian komórkowych badanego materiału biologicznego.

3. W celu sformułowania ostatecznych wniosków badania należy przeprowadzić dla zdecydowanie większej liczby szczepów bakterii.

\section{Literatura}

[1] Buda B., Dylus E., Górska-Frączek S., Brzozowska E., Gamian A.: Właściwości biologiczne białek powierzchniowych bakterii z rodzaju Lactobacillus. Post. Hig. Med. Dosw, 2013, 67, 229-237.

[2] Cieślik E., Gębusia A.: Charakterystyka właściwości prozdrowotnych owoców roślin egzotycznych. Postępy Fitoterapii, 2012, 13, 93-100.

[3] Cieślik E., Topolska K.: Skład chemiczny i właściwości funkcjonalne jagody acai (Euterpe oleracea Mart.). Postępy Fitoterapii, 2012, 13, 188-191.

[4] Cłapa T., Selwet M., Narożna D.: Życie w społeczności - warunki powstawania biofilmu. Kosmos, 2016, 65, 463-468.

[5] Currie C.R.: A community of ants, fungi, and bacteria: A multilateral approach to studying symbiosis. Ann. Rev. Microbiol., 2001, 55, 357-380.

[6] Czaczyk K.: Czynniki warunkujące adhezję drobnoustrojów do powierzchni abiotycznych. Postępy Mikrobiologii, 2004, 43, 267-283.

[7] Czaczyk K., Olejnik A., Miężał P., Grajek W.: Poszukiwanie prostych modeli do badania adhezji bakterii probiotycznych. Żywność. Nauka. Technologia. Jakość, 2005, 1 (42), 84-96.

[8] Donlan R.M.: Biofilms: Microbial life on surfaces. Emerg. Infect. Dis., 2002, 8, 881-890. 
[9] Duary R.K., Rajput Y.S., Batish V.K., Grover S.: Assessing the adhesion of putative indigenous probiotic lactobacilli to human colonic epithelial cells. Indian J. Med. Res., 2011, 134 (5), 664-671.

[10] Figueiredo A. de M., Biernet I. de C.: Assessment of the scientific evidence of the potential use of açaí (Euterpe oleracea, Mart.) in clinical outcomes: Analysis with focus on antioxidant and antiinflammatory action. Int. J. Nutrology, 2014, 7 (02), 26-32.

[11] Folin O., Ciocalteu V.: On tyrosine and thryptophane determinations in proteins. J. Biol. Chem., 1927, 73, 627-650.

[12] Hori K., Matsumoto S.: Bacterial adhesion: From mechanism to control. Biochem. Eng. J., 2010, 48 (3), 424-434.

[13] Jurkowski M., Błaszczyk M.: Charakterystyka fizjologiczno-biochemiczna bakterii fermentacji mlekowej. Kosmos, 2012, 61, 493-504.

[14] Kim J.S., Lee J.H., Surh J., Kang S.A., Jang K.H.: Aglycone isoflavones and exopolysaccharides produced by Lactobacillus acidophilus in fermented soybean paste. Prev. Nutr. Food Sci., 2016, 21, 117-123.

[15] Kos B., Suskovic J., Vukovic S., Simpraga M., Frece J., Matosic S.: Adhesion and aggregation ability of probiotic strain Lactobacillus acidophilus M92. J. Appl. Microbiol., 2003, 94 (6), 981-987.

[16] Koszowska A., Dittfeld A., Puzoń-Brończyk A., Nowak J.: Polifenole w profilaktyce chorób cywilizacyjnych. Postępy Fitoterapii, 2013, 14, 263-266.

[17] Lim S.M., Ahn D.H.: Factors affecting adhesion of lactic acid bacteria to Caco-2 cells and inhibitory effect on infection of Salmonella typhimurium. J. Microbiol. Biotechnol., 2012, 22 (12), 1731-1739.

[18] Lima G., Vianello F., Correa C., da Silva Campos R., Galhardo Borguini M.: Polyphenols in fruits and vegetables and its effect on human health. Food Nutr. Sci., 2014, 5, 1065-1082.

[19] Mobili P., Londero A., Maria T.M.R., Eusebio M.E.S., de Antoni G.L., Fausto R., Gomez-Zavaglia A.: Characterization of S-layer proteins of Lactobacillus by FTIR spectroscopy and differential scanning calorimetry. Vib. Spectrosc., 2009, 50, 68-77.

[20] Monds R.D., O'Toole G.A.: The developmental model of microbial biofilms: Ten years of a paradigm up for review. Trends Microbiol., 2009, 17, 73-87.

[21] Munoz-Provencio D., Llopis M., Antolin M., de Torres I., Guarner F., Perez-Martinez G., Monedero V.: Adhesion properties of Lactobacillus casei strains to resected intestinal fragments and components of the extracellular matrix. Arch. Microbiol., 2009, 191 (2), 153-61.

[22] Papuc C., Goran Gheorghe V., Predescu Corina N., Nicorescu V., Stefan G.: Plant polyphenols as antioxidant and antibacterial agents for shelf-life extension of meat and meat products: Classification, structures, sources, and action mechanisms. Compr. Rev. Food Sci. Food Saf., 2017, $16,1243-1268$.

[23] Piette J.P., Idziak E.S.: A model study of factors involved in adhesion of Pseudomonas fluorescens to meat. Appl. Environ. Microbiol., 1992, 58 (9), 2783-2791.

[24] Polak-Berecka M., Wasko A., Paduch R., Skrzypek T., Sroka-Bartnicka A.: The effect of cell surface components on adhesion ability of Lactobacillus rhamnosus. Antonie Van Leeuwenhoek, 2014, 106 (4), 751-762.

[25] Ren D., Li C., Qin Y., Yin R., Li X., Tian M., Du S., Guo H., Liu C., Zhu N., Sun D., Li Y., Jin N.: Inhibition of Staphylococcus aureus adherence to Caco-2 cells by lactobacilli and cell surface properties that influence attachment. Anaerobe, 2012, 18, 508-515.

[26] Schachtsiek M., Hammes W.P., Hertel C.: Characterization of Lactobacillus coryniformis DSM 20001T surface protein Cpf mediating coaggregation with and aggregation among pathogens. Appl. Environ. Microbiol., 2004, 70 (12), 7078-7085.

[27] Schillinger U.: Isolation and identification of lactobacilli from novel-type probiotic and mild yoghurts and their stability during refrigerated storage. Int. J. Microbiol., 1999, 47, 79-87. 
[28] Stepanovic S., Circovic I.C., Ranin L., Svabic-Vlahovic M.: Biofilm formation by Salmonella spp. and Listeria monocytogenes on plastic surface. Lett. Appl. Microbiol., 2003, 38, 428-432.

[29] Yamaguchi K.K.d.L., Pereira L.F.R., Lamarão C.V., Lima E.S., da Veiga-Junior V.F.: Amazon acai: Chemistry and biological activities: A review. Food Chem., 2015, 179, 137-151.

[30] Rozporządzenie Komisji (WE) nr 2073/2005 z dnia 15 listopada 2005 r. w sprawie kryteriów mikrobiologicznych dotyczących środków spożywczych. Dz. U. L 338, ss. 1-26, z 22.12.2005.

\section{EFFECT OF AÇAI BERRY (EUTERPE OLERACEA) EXTRACT ON SURFACE PROPERTIES, AUTOAGREGGATION, AND BIOFILM FORMATION BY BACTERIA OF LACTOBACILLUS GENUS}

\section{$\mathrm{Su} \mathrm{m} \mathrm{m} \mathrm{a} \mathrm{r} \mathrm{y}$}

In recent years, interest has increased in preparations containing Brazilian açai berries (Euterpe oleracea). The açai berry extracts are characterized by a high content of organic compounds, such as proteins or lipids. Attention is drawn to the pro-health and, in particular, antioxidant properties of that fruit. A high antioxidant potential of açai berry extracts is determined by a high content of polyphenolic compounds that can be isolated from their flesh. When consumed by humans and animals, the polyphenolic compounds present in plant extracts have a considerable impact on the modulation of intestinal microflora. Depending on the origin and the dose of extract used, they can become activators or inhibitors of the growth of commensal bacteria. In the research study, there was analysed the effect of the açai berry preparation on bacteria with probiotic potential from the Lactobacillus genus. An analysis was carried out to determine the rate of biofilm formation by bacteria depending of the presence of açai berry preparation in the culture medium. It was tested how the açai fruit preparation affected the ability of bacteria to autoaggregate and their affinity to organic solvents. The studies performed showed the effect of açai berry preparation on the autoaggregating capacity of Lactobacillus spp. (a reduction in the autoaggregation of Lactobacillus brevis strains and an increase in the autoaggregation of Lactobacillus casei bacteria). Among all the tested strains of Lactobacillus spp., a reduction was reported in the biofilm formation capacity in the environments with the açai berry preparation added. In addition, the açai berry preparation affected the donor-acceptor type of properties of Lactobacillus spp cell walls.

Key words: Lactobacillus, acai berry, autoaggregation, biofilm 